\title{
Nándor Dreisziger
}

\section{Genetic Research and Hungarian "Deep Ancestry"}

\begin{abstract}
The past few decades saw the birth of the new science of genetics that can be used not only for medical purposes but also for the study of the past. Geneticists were quick to begin applying this science to the examination of Hungarian history, especially the subject of Hungarian origins. The purpose of this paper is to acquaint the reader with some of these studies. One study this paper will examine is itself a review of the scientific literature of early genetic studies on Hungarian origins. Other studies evaluated in this paper will be the English-language scientific publications of a team of Hungarian geneticists who over the last several years have studied the genetic inter-relatedness of $10^{\text {th }}$ century and present-day Hungarian populations in the Middle Danube Valley of Central Europe. The paper comes to the conclusion that while very early genetic inquiries into Hungarian origins were often fault-ridden and are of little use now, more recent studies suggest that the currently held explanations of Hungarian ethnogenesis especially the story of the so-called Hungarian conquest of the late $9^{\text {th }}$ century - might very well be subjected to a fundamental re-assessment.
\end{abstract}

For many centuries the study of Hungarian ethnogenesis - and in particular the antecedents, events and consequences of the Hungarians' arrival in Central Europe's Carpathian Basin - relied on the traditional disciplines of history, archaeology, physical anthropology, paleo-linguistics, or paleo-musicology. In the second half of the $20^{\text {th }}$ century a new science, the science of genetics, began to be used in the quest to find out more about the question who were the ancestors of the Hungarians, and in particular, who were the peoples that gave birth to a nation that began to emerge a millennium ago in the Hungarian homeland. A quantum leap in our knowledge of genetics came around the turn of the millennium when the human genome was decoded and geneticists began understanding the nature and functions of SNPs (single nucleotide polymorphisms) which are snippets found in the DNA chain. At about the same time geneticists also found that by studying the DNA (and, especially the SNPs) in the y-chromosome of males, and to a lesser extent the DNA in the mitochondria of women, they could throw light on the interrelatedness of human groups in the past, as well as on their migrations throughout the ages. These advances in scientific knowledge heralded the arrival of a new branch of genetics, the science of genomics. In the decade since the decoding of the human genome scientists have made further advances in genetics. These included the discovery of millions more SNPs - even SNPs in genomic DNA. (For information on SNPs, including their role as biological markers and predictors of human diseases, see <http:/ghr.nlm.nih.gov/handbook/genomicresearch/snp> and other similar websites.)

For students of genomics the importance of these SNPs is that they are remarkably stable. They are passed down from one generation to the next unaltered. However, once every several hundred generations a SNP mutates, and from that time on it is passed on to the members of subsequent generations in its new, mutated form. This process makes it possible for geneticists to follow the evolution of the human family tree, as they can sort individuals into different groups depending on what combination of SNPs they have, or don't have, in their DNA. Not surprisingly the science of genomics is often called the science of "deep ancestry". 
As has been mentioned, students of deep ancestry have been focusing mainly on y-chromosomal DNA and mitochondrial DNA. The former is usually designated as $y-$ DNA and the latter as mt-DNA. Y-DNA is found in the nucleus of the y-chromosome of men, while mt-DNA is found in the region of each human cell known as the mitochondria. Because women don't have a y-chromosome, y-DNA is passed only from fathers to their sons. Mt-DNA can be found in both women and men, but it is not passed from father to son, only from a mother to her infants. Because of such characteristics of these types of DNA, y-DNA is a tool for the study of male lineages, while mt-DNA is used to study female lineages.

There are other differences between these two types of DNA. Y-DNA is more complex and contains far more SNPs than mt-DNA. Another difference between the two is not physiological but societal. From the study of the incidence of mt-DNA types in women and y-DNA types in men, scientists have come to the conclusion that in the past women were far less likely to migrate than men. That is, if someone wants to study the migrations of human populations, a study of y-DNA will yield richer results than a study of the study of mt-DNA. It might be added that in some societies the study of mt-DNA and the study of y-DNA indicate huge differences between the ancestry (and therefore the history) of women and men. A classic example is Mexico where mt-DNA tests show that a predominant majority of women are descendants of the original native populations while y-DNA tests reveal that the male population of the country is largely of European origin.

The appearance of the new science of genetics, and later of genomics, resulted in a number of studies that attempted to apply these new disciplines to the question of the origins of the Hungarians. A few of these early genetic studies relating to Hungarian ethnogenesis are the subject of the paper by Csanád Bálint. Bálint, who is the Director of the Hungarian Academic of Sciences' Institute or Archaeology, first examined the publications of the internationally-known geneticist L. L. Cavalli-Sforza of Stanford University (especially his The History and Geography of Human Genes [various editions]). The very first point Bálint makes, is that in his studies of the genetic composition of the peoples of Europe Cavalli-Sforza concentrated on members of the Indo-European linguistic family tree almost to the exclusion of that other linguistic family tree in Europe, the Uralic. And when he did make comments on Finno-Ugrians, Cavalli-Sforza made gross mistakes. Sometimes, according to Bálint, the California scientist made so many mistakes in a single sentence that he became "immediately discredited" (284-85). According to Bálint, Cavalli-Sforza doesn't even know what languages belong to the Uralic family tree. While these mistakes should not "affect the general evaluation" of the scientist's work, Bálint argues, it should reveal the depth, or rather the lack of it, of his knowledge of things Hungarian (285).

Bálint next moves on to a discussion of a paper by C. R. Guglielmino and other scientists. Here Bálint finds even more, and even more serious mistakes, despite the fact that one of the study's authors (Judit Béres) is a Hungarian. Guglielmino's study, according to Bálint, is especially confused regarding the origins of various ethnic components of Hungary's population, such as the Palóc, the Cumans, the Csángo, the Székely, and the Jász people. Bálint also lambastes the study's authors for suggesting that the Hun language, in fact elements of the Hun nation, still existed at the end of the $9^{\text {th }}$ 
century. "Similar ideas," he writes, "can be read only in dilettante writings from Hungary" (288).

The next work Bálint considers is the Magyar-language monograph of the Hungarian geneticist Endre Czeizel, A magyarság genetikája [The Genetics of the Hungarians] (Debrecen, 1990; Bálint used the 2003 edition). In dealing with this work, Bálint avoids the giving of a long list of minor errors though he lists a few and suggests that more are present in the book, just as they were present in the paper by Guglielmino. (Here Bálint spells the name Guglielmo [sic]) (289). Instead, he concentrates on the book's final conclusions, according to which Hungarians inherited most of their genes (48 to $78 \%$ of them) from Iranians and therefore they are fundamentally of Iranian origin. According to Bálint, these conclusions are wrong for three reasons: 1. they call into question the Finno-Ugrian nature of the Magyar language; 2. they do not explain the strong cultural links between Hungarians and Turkic peoples; and 3. they are not in congruence with the findings of physical anthropology about $10^{\text {th }}$ century Hungarians. Bálint emphasizes that Iranian peoples had contributed to the genetic and cultural makeup of the Hungarian nation, no doubt even beyond the legacy of the Sarmatian and Alan peoples that had lived in the Carpathian Basin before the Hungarian conquest - and the Jász who migrated to Hungary in the $13^{\text {th }}$ and $14^{\text {th }}$ centuries.

The last genetic study Bálint reviews is a study published by András Zs. Bíró and his team. As background to this subject we should state that in the 1960s a physical anthropologist by the name of T. Tóth, on a visit to the Soviet Union, "discovered" a clan in Kazakhstan called the Madijars and concluded that these people were Magyars. Decades later another Hungarian traveller, M. Benkö, visited the region and again declared this clan a relative of the Hungarian nation. Following this, Bíró and his team went to visit the Madijars and were greeted enthusiastically as long-lost relatives. Bálint points out that Bíró and his associates referred to this clan not by their real name, Madijars, but by a name they gave them: Madjars. Bíró and the members of his team managed to obtain y-DNA samples from a group of Madijar men and eventually compared the results with the y-DNA of another rather small group of Hungarian men. To make a long story short, Bíró and his associates came up with the conclusion that genetic evidence also supported their conclusion about the relatedness of Madijars and Magyars. What upset Bálint even more is that these geneticists - who, according to Bálint, had no qualifications as historians, linguists or ethnographers - on the basis of such limited evidence suggested that the ancient homeland of Hungarians must have been in Central Asia.

The writer of these lines cannot but sympathize with Bálint's view. The y-DNA tests done on Madijar men indicate that they are so distant genetically from Hungarians that any relationship between the two peoples is inconceivable. Crudely put, the argument used by Bíró and company sounds like this: the Madijars are genetically extremely distant from all other populations, and they are very distant from Hungarians: therefore they must be the closest relatives of Hungarians. The major question that all this leaves for the writer of these lines (a question Bálint does not ask explicitly): how did Bíró and his team succeed in publishing an article on this subject in a major western scientific journal? The answer might be, and Bálint hints at this, that the study contributed to the knowledge of the y-DNA of a Central Asian population, when this kind of knowledge is very limited and therefore precious. 
Undoubtedly Bálint is right in pointing out that most geneticists have limited knowledge of Hungarian history and ethnography, and commit myriad errors when they write about the Hungarian past and even the present. Beyond this we might wonder what was useful about writing reviews of three genetic studies that by the end of the first decade of the $21^{\text {st }}$ century had become quite outdated - and a fourth one that is obviously flawed? Is Bálint trying to create the impression that the science of genetics cannot make significant contributions to the study of the Hungarian past? Still another question that comes to the mind is why Bálint did not review other genetic studies that have at least some relevance to the subject of Hungarian ethnogenesis? One such study is the paper which Ornella Semino, Giuseppe Passario, Peter J. Oefner and their very numerous co-authors published in the journal Science in November of 2000. This study might also have been criticized, perhaps not so much for identifying Poles and Ukrainians as the Hungarians' alleged "closest" genetic relatives - a conclusion that requires some explanations and qualifications - but for arriving at wrong results concerning the ratio of y-DNA haplogroups among present-day Hungarian men. This wrong result is mainly the consequence of Semino and team using a small sample pool (the study's authors were familiar with the y-DNA of only 45 Hungarian men).

In the rest of my essay I want to make up, to some extent at least, for what might be considered as missing in Bálint's paper — and talk about the results of other genetic research that has relevance for the subject of Hungarian ethnogenesis.

In this connection I want to review three papers that had been published in the course of the last four years by a team of geneticists and other experts headed by István Raskó, one of Hungary's best-known genetic scientists. It should be mentioned that these studies were undertaken with the explicit aim of shedding more light on Hungarian ethnogenesis, more precisely on the so-called Hungarian conquest of the Carpathian Basin at the end of the $9^{\text {th }}$ century. The project was undertaken with great expectations and the writer of these lines suspects that one of its supporters had been Csanád Bálint himself.

The project involved the collection of DNA samples from two sources: from people living in Hungary and the Székelyland of Transylvania (today in Romania) at the present, and from the skeletal remains of people buried in $10^{\text {th }}$ century greaves in the Carpathian Basin. This "ancient group" was divided into two further categories. One of these was made up of the "classical conquerors" whose graves were characterised by rich grave goods typical of members of $10^{\text {th }}$ century Hungary's military-political elite, and the other group was made up of $10^{\text {th }}$ century commoners, i.e., the subject peoples of the age as revealed by the poverty of their grave goods - or their complete absence. The first publication that resulted from this auspicious research project appeared in 2007 and reported on the research team's findings concerning mt-DNA.

The researchers compared the mt-DNA of the modern Hungarian (including Székely) populations with the mt-DNA of the two groups of the ancient ones. This comparison revealed that the genetic distance between the present-day populations' $\mathrm{mt}-$ DNA and the mt-DNA of the occupants of graves of the elite was great, while variance between the mt-DNA of people found in common graves and the mt-DNA of modern Hungarians was "negligible." This suggests that modern-day Hungarian and Székely women are not the descendants of the wives and daughters of the conquerors, but that they might very well be the descendants of the people in commoners' graves. These 
findings strongly suggest a genetic link between the region's pre-conquest population and its present-day people. The finding that many present-day women in Hungary and the Székelyland are related by blood to the common people of the Carpathian Basin in the $10^{\text {th }}$ century is significant. It means that immigration into this part of Europe in the last millennium, however substantial it had been at times, did not result in a complete replacement of the region's population.

The second article under consideration resulted from the Raskó team's research that examined the DNA of men, the so-called y-chromosomal DNA. In this project the researchers looked for the incidence of Tat polymorphism, i.e., the Tat $\mathrm{C}$ allele, in the $\mathrm{Y}$ chromosomal DNA of two populations: male occupants of $10^{\text {th }}$ century elite graves and modern-day Hungarian and Székely men. The results of the investigation were surprising. The research revealed that while among the conquerors the Tat polymorphism was common, among the modern samples it was virtually absent (only one man, a Székely, was found carrying the Tat $\mathrm{C}$ allele). To put it in another way, the researchers found that many of the conquerors, i.e., Prince Árpád's warriors, belonged to the N1c1 human yDNA haplogroup, and they also found that as far as the 200 modern y-DNA sample indicated, not a single resident of present-day Hungary was a member of this group. In other words, they found no genetic connection between Árpád's warriors and Hungary's present-day male population.

It might be added to a discussion of this project that DNA research by other geneticists since the Raskó's project have found one or two more men in the Carpathian Basin (one of them in Slovakia) who belong to the N1c1 haplogroup, and a few more Székely men who might also prove to be members of this group should they receive a more complex DNA test. As far as people in Hungary proper are concerned however, it seems that someone with the Tat $\mathrm{C}$ allele in his $\mathrm{y}$-DNA has yet to be found. What does this mean in practical terms? It means that a large portion, possibly the majority of Hungarian men cannot possibly be the direct descendants of the nomadic warriors who occupied the Carpathian Basin at the end of the $9^{\text {th }}$ century.

Very recently still another genetic study appeared that relates directly to the subject of Hungarian ethnogenesis. This was also done by Raskó and some members of his team of Hungarian and international geneticists, and it studied the subject of genetically influenced lactose intolerance in two populations: present-day Hungarians living in Hungary and in the Székelyland on the one hand and the immediate descendants of the "conquerors" as well as their subject peoples who lived in $10^{\text {th }}$ century Hungary on the other. The DNA used in this study came from the same sources for DNA analysis that these and other members of Raskó's team had used for their mt-DNA and Y-DNA studies that had been described above.

The team's new study focused in large part on the incidence of the $\mathrm{T}_{-13910}$ autosomal allele (which makes an individual lactose tolerant) among the two population groups mentioned above. The study's findings were again remarkable. Among the "conquerors" the incidence of this allele was zero (which means that they all had the condition known as lactose intolerance). Among the "commoners" - who were most likely the children or grandchildren of the autochthonous, i.e., pre-conquest inhabitants of the Carpathian Basin - it was 28\%; while among present-day residents of Hungary and of the Székelyland it was $35.9 \%$ and $40 \%$, respectively. The study's authors also examined the incidence of the $\mathrm{C} / \mathrm{T}_{-13910}$ allele among the populations they studied. They 
came to the conclusion that "Significant difference was found[,]" in regard to this "...between the ancient Hungarian conquerors and the present-day Hungarian-speaking populations... [but] [n]o significant difference was found between the present-day Hungarian-speaking populations and ancient... commoners." These results clearly indicate that the "classical conquerors" were members of a different ethnic group than the population they conquered. They also suggest that the present-day Hungarian populations (both in Hungary and in the Székelyland) are on the whole not the descendants of the "conquerors" but are the progeny of the Carpathian Basin's pre-conquest population.

Still another finding of Professor Raskó's team is even more important. The team's members concluded that the "conquerors", who arrived in the Carpathian Basin at the end of the $9^{\text {th }}$ century, were not numerous. In one of their studies the team pointed out that, once the conquerors established themselves there, they made up only a "small fraction" of that land's total population. If this had been otherwise, i.e., if the conquerors had constituted a sizeable population, they would have left some kind of a "genetic footprint".

We have to keep in mind that the conclusion that the conquering population was small, is not new. More than a century ago archaeologist József Hampel (1849-1913) came to the same opinion, i.e., the conquering "Hungarians" were "only a small minority" of the $10^{\text {th }}$ century Carpathian Basin's population. The list of prominent scholars who shared this view is long. One of them was the eminent medievalist Elemér Mályusz (1898-1989) who estimated the size of the conquering population at 70,000. Two others were archaeologists István Erdélyi and János Makkay who gave the number "at most 100,000." Then there was historian-archaeologist Gábor Vékony (1944-2004) who didn't give a number but suggested that the conquerors, when settled in the new homeland, made up about one percent of its total population.

We have to emphasize that Raskó and his team don't claim to have made an attempt to re-write the history of Hungarian ethnogenesis. They never suggested that, for example, the conquerors were not Hungarian-speaking. In one of their studies they declared that the autochthonous population of the Carpathian Basin at the end of the $9^{\text {th }}$ century was mainly Slavic - and added that the conquerors, because of their superior political and social position, "imposed" their language on the locals. This of course is faulty logic. There had been at least a dozen examples of warrior tribes conquering settled peoples in early medieval Europe and in every one of these conquests the autochthonous peoples assimilated the conquerors rather then the other way around. Had the locals in the Carpathian Basin really been predominantly Slavs, the people of Hungary would be speaking a Slavic language today.

After these comments we may ask just whose theory of Hungarian ethnogenesis do the Raskó team's researches support? They certainly do not support the theory held by most historians in Hungary, including Csanád Bálint. But they support the theories of a handful of Hungarian scholars. We need not go back more than half a century, even though there had been historians who held alternative explanations of the Hungarian conquest even then. We might just mention archaeologists Vékony, Makkay and, above all, Gyula László. In the 1970s László and Makkay were known as the founders of the "Dual Conquest" theory of Hungarian ethnogenesis. At the time this theory was generally interpreted as saying that the ancestors of the Magyars arrived in Central Europe two waves: once at the end of the $9^{\text {th }}$ century and once some 220 years earlier. By the mid- 
1990s however both László and Makkay defined the meaning of their theory differently. A quotation from László will explain: "...the Hungarians of the Middle Ages and the Hungarians of today are on the whole not the progeny of Árpád's conquerors but the direct descendants of the earlier Onogur, late-Avar people." Historian Vékony also argued that the conquerors on the one hand and the ancestors of the Hungarians both of the Middle Ages and of today on the other, were not members of the same ethnic or linguistic group.

At this point we may ask how did the Hungarian nation get stuck with the argument that all the Magyars' ancestors arrived in the Carpathian Basin at one time, at the end of the $9^{\text {th }}$ century (my emphasis)? The writer of these lines suspects that this happened because this was the myth that had been propagated by members of the Árpádian ruling house of Hungary who ruled the country for four centuries — and, in fact, Hungary's elite subscribed to this myth throughout a millennium of history. Just as in the United States millions of citizens trace their ancestry to the people who arrived in the New World on the ship Mayflower, in Hungary the elite, and in fact the general public believes that they are mostly the descendants of Prince Árpád and his nomadic warriors. To suggest that Árpád's people might not have been Magyar-speaking, is tantamount to treason in the eyes of many of these people.

Old myths rarely die, or die very slowly. To counter any "alternative" theories of Hungarian ethnogenesis, most Hungarian historians have been overestimating the numbers of the conquering people and vastly underestimating the size of the Carpathian Basin's pre-conquest population. They have also been holding on to scarps of evidence that support their theory and ignoring clues that don't.

Will the three studies by Raskó's team change this situation? Unlikely. Even the team's members (at least the ones I contacted) are not aware of the revolutionary nature of the evidence they produced. Nor is the public in Hungary aware of it. And, we have to admit, the Raskó team's conclusions have been based on a minuscule number of samples, especially as far as the numbers of the "ancient Hungarians" are concerned. Scholars, especially those who insist on upholding the "old" theory of Hungarian ethnogenesis, will no doubt dismiss these results as meaningless.

Until a new genetic research project on Hungarian ethnogenesis will be undertaken, with much more generous funding than the previous one, the old theory of Hungarian ethnogenesis will no doubt rein unchallenged in Hungary, and scholars such as Makkay, Vékony, and even László (as well as the others) will become increasingly forgotten.

\section{A Note on Sources}

There are probably thousands of books that deal with Hungarian ethnogenesis. Here all I want to do is list a few that offer explanations that differ from the predominant theory and I mention only one book for each author.

Perhaps the best known of such works is: Gyula László, A „,kettős honfoglalás." (Budapest: Magvetö, 1978). A somewhat less-known book is János Makkay, A magyarság keltezése (Szolnok: Jász-Nagykun-Szolnok Múzeum, 1994. $2^{\text {nd }}$ edition). And the third book is Gábor Vékony, Magyar östörténet - Magyar honfoglalás. (Budapest: Nap Kiadó, 2002). 
As far as articles by these authors are concerned I mention only two, out of the hundreds they published: János Makkay, "Embertannal kapcsolatos adatok a 'kettős honfoglalás' vitájához" (Anthropological Data Concerning the Debate About the 'Dual Conquest'), Anthropológiai Közlemények, 35 (1993): 213-19; and Gyula László, "Életem egyik fele, a régészet" (One Half of My Life, Archaeology). Akadémiai beszélgetések, 17 April 1997, <http://www.mmakademia.hu/ab/3/303.php>.

A genetic study mentioned in my review but one that had not been reviewed by Bálint is Ornella Semino et al. "The Genetic Legacy of Paleolithic Homo sapiens sapiens in Extant Europeans: A Y Chromosome Perspective," Science, vol. 290 (November 2000): 1155-59. Still another relevant but rather outdated work is C.R. Gugliemino, A. Piazza, P. Menozzi, and L.L. Cavalli-Sforza, "Uralic Genes in Europe," American Journal of Physical Anthropology, 83, 1 (Sept. 1990): 57-68.

Among my publications that relate to the subject of Hungarian ethnogenesis I mention only the following, which in a large part is a detailed review of Vékony's book on the subject. Nándor Dreisziger, "The Székelys: Ancestors of Today's Hungarians? A New Twist to Magyar Prehistory," Hungarian Studies Review, 36, 1-2 (2009): 153-69.

This review article is available on the internet at:

<htpp://www.hungarianstudies.org/HSR2009.pdf>.

\section{A postscript to the note on sources:}

Since I wrote this article a few works have come to my attention that relate to the subject of the "Hungarian conquest" of the Carpathian Basin. The most important of these is undoubtedly Péter Király, A honalapítás vitás eseményei [The disputed events of the establishment of a homeland] (Nyíregyáza: Nyíregyházi Főiskola, 2006). In this monograph Professor Király argues that a study mainly of written sources related to the arrival of the ancestors of Hungarians in the Carpathian Basin suggests that their first settlement there took place at the end of the 6th century rather than at the end of the 9th as is generally believed. (See especially p. 214 of his book.)

\section{Works Cited}

Csanád, Bálint. 2010. "Some Problems in Genetic Research on Hungarian Ethnogenesis." Acta Archaeologica Acadeniae Scientiarum Hungariae. 61: 283-94.

Csányi, Bernadett, Erika Bogácsi-Szabó, Gyönyvér Tömöry, Ágnes Czibula, Katalin Priskin, Aranka Csősz, B. Mende, Péter Langó, K. Csete, A. Zsolnai, E. K. Conant, C. Stephen Downes and István Raskó. 2008. "Y-Chromosome Analysis of Ancient Hungarian and Two Modern Hungarian-Speaking Populations from the Carpathian Basin." Annals of Human Genetics, 72: 519-34.

Nagy, Dóra, Gyöngyvér Tömöry, Bernadett Csányi, Erika Bogácsi-Szabó, Ágnes Czibula, Katalin Priskin, Olga Bede, László Bartosiewicz, C. Stephen Downes, and István Raskó. 2011. "Comparison of Lactose Persistence Polymorphism in Ancient and Present-Day Hungarian Populations." American Journal of Physical Anthropology. Available online. 
Tömöry, Gyönyvér, Bernadett Csányi, Erika Bogácsi-Szabó, Tibor Kalmár, Ágnes Czibula, Aranka Csősz, Katalin Priskin, Balázs Mende, Péter Langó, Stephen C. Downes, István Raskó. 2007. "Comparison of Maternal Lineage and Biogeographic Analyses of Ancient and Modern Hungarian Populations." American Journal of Physical Anthropology. 134: 354-68. 